\title{
Streptococcus agalactiae Native Valve Endocarditis: Uncommon Presentation of Multiple Myeloma
}

\section{Endocardite a Streptococcus agalactiae: Manifestação Incomum de Mieloma Múltiplo}

Ana PINHO OLIVEIRA $\rrbracket^{1}$, Anne DELGADO², Cláudia MARTINS ${ }^{1}$, Pedro GAMA $^{2}$

Acta Med Port 2016 Jul-Aug;29(7-8):488-490 - http://dx.doi.org/10.20344/amp.7246

ABSTRACT

Adults with chronic immunosuppressive conditions are at an increased risk for Streptococcus agalactiae endocarditis, which is typically characterized by acute onset, presence of large vegetations, rapid valvular destruction and frequent complications. We report a rare case of a 74 years old man presenting with fever, renal infarction, ischemic stroke and uveitis. Infective endocarditis was diagnosed and Streptococcus agalactiae was isolated in blood cultures. A multiple myeloma Ig G-K was also diagnosed. The infective endocarditis was successfully treated with a course of benzylpenicillin and gentamicin. The authors highlight the severity of vascular embolic disease present in this case and the diagnostic challenge. They also intend to remind about the association between Streptococcus agalactiae endocarditis and chronic diseases, despite its low reported prevalence.

Keywords: Endocarditis, Bacterial; Multiple Myeloma; Streptococcal Infections; Streptococcus agalactiae.

\section{RESUMO}

Adultos com doenças imunossupressoras crónicas apresentam risco aumentado de endocardite a Streptococcus agalactiae, caracterizada por clínica de início súbito, vegetações de grandes dimensões, destruição valvular rápida e complicações frequentes. Relatamos o caso de um doente de 74 anos de idade, admitido por quadro febril associado a enfarte renal, acidente vascular cerebral e uveíte, com o diagnóstico subsequente de endocardite infeciosa, tendo-se objetivado bacteriemia a Streptococcus agalactiae. Simultaneamente foi diagnosticado mieloma múltiplo lg G-K. A endocardite infeciosa foi tratada com sucesso recorrendo a antibioterapia com benzilpenicilina e gentamicina. Os autores destacam a gravidade da doença embólica vascular presente neste caso e o desafio diagnóstico. Pretendem ainda relembrar a associação entre endocardite a Streptococcus agalactiae e as doenças crónicas, apesar da sua baixa prevalência.

Palavras-chave: Endocardite Bacteriana; Infecções Estreptocócicas; Mieloma Múltiplo; Streptococcus agalactiae.

\section{INTRODUCTION}

Multiple myeloma (MM) comprises $1 \%$ of all cancers, ${ }^{1,2}$ being the second most common blood cancer after lymphomas. ${ }^{2}$ Plasma cells neoplasm causes an increase of M-protein in the serum and a decrease in the serum level of normal immunoglobulin. ${ }^{9}$ As a consequence, bacterial infections often complicate the clinical course of MM and are the leading cause of morbidity and mortality in these patients. ${ }^{3}$ Although bacteremia is a common complication in this disorder, infective endocarditis (IE) is diagnosed only in a few cases, with an incidence ranging from $0.4 \%$ to $4.7 \%$ per year in patients with $\mathrm{MM}$ and bacteremia. ${ }^{3}$ Occasionally, the first manifestation of an underlying MM may be an episode of acute bacterial infection. ${ }^{4}$ Adults with chronic immunosuppressive conditions are at an increased risk for Streptococcus agalactiae endocarditis, ${ }^{5}$ which is characterized by acute onset, large vegetations, rapid valvular destruction and frequent complications. ${ }^{6}$ Its clinical course is more aggressive than IE caused by other Streptococcus species ${ }^{6}$ and the mortality rate exceeds $40 \% .5,7$

\section{CASE REPORT}

A 74 years old man, without relevant history of disease, came to the emergency department complaining about bilateral back pain, without irradiation, which started about one week earlier, associated with walking limitation. He also mentioned concomitant night sweats, aqueous vomiting and constipation. There were no other complaints. On physical examination the patient was febrile (tympanic temperature of $38.5^{\circ} \mathrm{C}$ ) but no other changes were noted, including heart murmur, splinter haemorrhages, Janeway's lesion or conjunctival haemorrhages. Laboratory data showed macrocytic anemia, neutrophilia and elevated C-reactive protein and erythrocyte sedimentation rate. Lumbar spine computed tomography (CT) and abdominal ultrasound showed no changes and, in the absence of symptomatic relief, an abdominal contrast-enhanced CT was performed, which revealed two parenchymal focuses on the left kidney suggestive of renal infarctions and complete thrombosis of the left common iliac vein. Low molecular weight heparin in therapeutical dose was initiated and the patient was admitted to internal medicine department for further study. The patient also referred sudden right amaurosis and, upon ophthalmic examination, an endogenous right panuveitis was diagnosed and corticosteroids prescribed. Roth spots were absent. On the first day of hospitalization the patient

\footnotetext{
1. Serviço de Medicina. Centro Hospitalar Tondela-Viseu. Viseu. Portugal.

2. Serviço de Cardiologia. Centro Hospitalar Tondela-Viseu. Viseu. Portugal.

$\square$ Autor correspondente: Ana Pinho Oliveira. ana_ip_oliveira@hotmail.com

Recebido: 04 de dezembro de 2015 - Aceite: 20 de junho de 2016 | Copyright @ Ordem dos Médicos 2016
} 
had generalized tonic-clonic seizures. Brain CT showed an ischemic lesion on the posterior inferior cerebellar artery territory. The hypothesis of an embolic etiology was raised and a transthoracic echocardiogram was performed, revealing an image suggestive of vegetation measuring 2.1 $\mathrm{cm} \times 0.6 \mathrm{~cm}$ in the mitral valve associated with mild mitral regurgitation (Fig. 1). According to the Duke criteria, native valve IE was assumed and antibiotherapy with amoxicillin and clavulanic acid associated with gentamicin was initiated. Further etiologic study of this prothrombotic state revealed a monoclonal gamma spike-like peak on serum protein electrophoresis and, after immunoglobulin and light/ heavy chain dosing and bone marrow aspirate, a stage II MM Ig G-K was diagnosed. Blood cultures were positive for penicillin sensitive Streptococcus agalactiae, and antibiotherapy was changed to intravenous benzylpenicillin plus gentamicin (four and two weeks, respectively). Chemotherapy for MM was delayed until infection resolution (Fig. 2) and only systemic corticosteroids were used until then. A standard oral melphalan-prednisone protocol was then initiated. Later, bortezomib was added to this scheme instead of thalidomide due to previous thrombotic events.

\section{DISCUSSION}

Streptococcus agalactiae IE remains an uncommon cause of acute endocarditis. ${ }^{6}$ However, its demographic characteristics and outcome have changed over time. ${ }^{5}$ The typical patient with Streptococcus agalactiae endocarditis in the pre-antibiotic era was a young woman with mitral disease who was pregnant or in labor (it colonizes the female genital tract, the throat and the rectum). Currently, Streptococcus agalactiae IE presents in older patients with underlying severe chronic diseases and affects left-sided valves as was the case of our patient. ${ }^{7,8}$ The susceptibility of infants and women in pregnancy and postpartum to group $B$

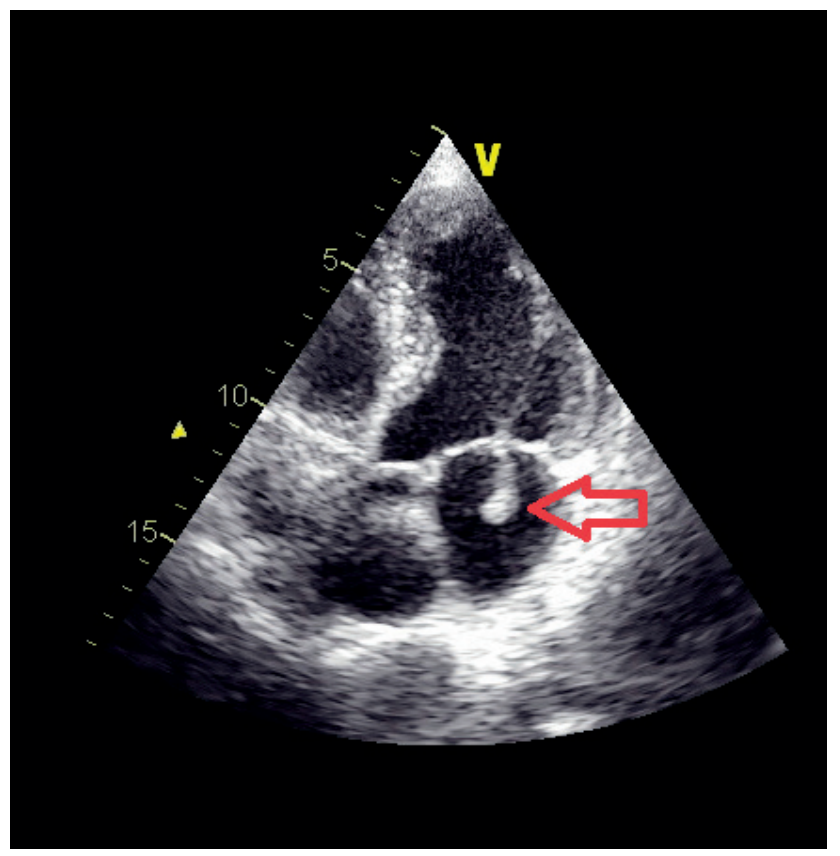

Figure 1 - Transthoracic echocardiogram, apical five chamber view. The arrow points to the vegetation. streptococcal disease depends on the level of type-specific capsular antibodies in maternal serum. The role of these antibodies outside pregnancy remains unclear ${ }^{7}$ but the proposed immunological mechanisms includes functional hypogammaglobulinaemia, numerical and functional abnormalities of dendritic and T cells and natural killer cells dysfunction. ${ }^{9}$ Approximately $2 \%$ to $9 \%$ of Streptococcus agalactiae bacteremias are complicated with IE, which is an aggressive disease with a high rate of local and systemic complications. ${ }^{7}$ Systemic embolization, described in some series to be present in up to $50 \%$ of cases, ${ }^{7}$ is frequently the first sign of disease. Large valvular vegetations are thought to explain the high rate of embolic events. ${ }^{10,11}$ Central nervous system involvement is frequent and similar to Enterococcus IE, but presents in a shorter period of time, which has been related with the lack of Streptococcus agalactiae fibrinolysin production in the vegetations..$^{5}$ This fact complicates the evolution of these patients and worsens the vital prognosis. ${ }^{5,11}$ In general strains of Streptococcus agalactiae are slightly more resistant to penicillin than strains of other streptococcus; thus, an aminoglycoside must be added during the first two weeks of treatment, which should last four to six weeks. ${ }^{7}$ Renal events are less frequently described despite having been the initial manifestation in this patient. ${ }^{7}$ Left common iliac vein thrombosis was interpreted has a paraneoplastic syndrome. Ophthalmologic involvement in IE cases is uncommon. According to Siccion et $\mathrm{al}^{12}$ group B streptococcus were the etiologic agent in $7 \%$ of endogenous endophthalmitis and the main source of infection was IE. These patients typically experience a dramatic vision loss. Uveitis, a non-infectious inflammatory disease that can easily be mistaken as endophthalmitis, is considered to be an immunologic response to exogenous and endogenous antigens but the exact mechanism is still poorly understood. ${ }^{6}$

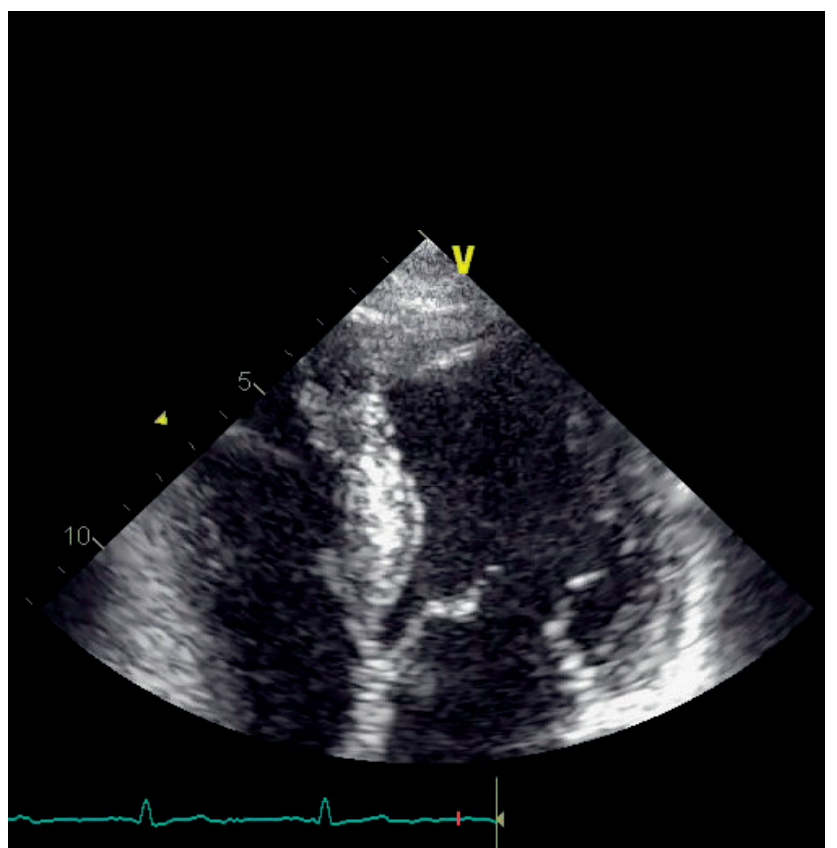

Figure 2 - Control transthoracic echocardiogram showing the complete resolution of the vegetation in the mitral valve 
Surgical treatment is recommended in the presence of embolic events and vegetation size $>10 \mathrm{~mm} .{ }^{11}$ However, in this case, surgery was not performed due to patient comorbidities and favorable evolution under antibiotic therapy.

The presented case is a rare example of Streptococcus agalactiae native mitral valve endocarditis with uveitis, renal infarction and ischemic stroke unmasking a previously undiagnosed MM. The authors highlight the severity of vascular thrombosis present in this case and the diagnostic challenge. We hope to provide further insight on the management of similar cases, which can be fatal without prompt treatment.

\section{PROTECTION OF HUMANS AND ANIMALS}

The authors declare that the procedures were followed according to the regulations established by the Clinical Research and Ethics Committee and to the Helsinki Declaration of the World Medical Association.

\section{DATA CONFIDENTIALITY}

The authors declare having followed the protocols in use at their working center regarding patients' data publication.

\section{CONFLICTS OF INTEREST}

The authors declare that there are no conflicts of interest.

\section{FUNDING SOURCES}

No subsidies or grants contributed to this work.

8. Song MJ, Kim WH, Lee SH, Lee SR, Rhee KS, Chae JK, et al Infective endocarditis due to streptococcus agalactiae in young and immunocompetent woman: a case of structurally normal valve endocarditis presented with major stroke. J Cardiovasc Ultrasound. 2011;19:38-40.

9. Nucci M, Anaissie E. Infections in patients with multiple myeloma in the era of high-dose therapy and novel agents. Clin Infect Dis. 2009;49:1211-25.

10. Ivanova Georgieva RI, Garcia López MV, Ruiz-Morales J, MartínezMarcos FJ, Lomas JM, Plata A, et al. Streptococcus agalactiae left-sided infective endocarditis. Analysis of 27 cases from a multicentric cohort. J Infection. 2010;61:54-9.

11. Habib G, Lancellotti P, Antunes MJ, Bongiorni MG, Casalta JP, Del Zotti $F$ et al. 2015 ESC guidelines for the management of infective endocarditis: The Task Force for the Management of Infective Endocarditis of the European Society of Cardiology (ESC). Endorsed by: European Association for Cardio-Thoracic Surgery (EACTS), the European Association of Nuclear Medicine (EANM). Eur Heart J. 2015;36:3075-128.

12. Chihara S; Siccion E. Group B streptococcus endocarditis with endophthalmitis. Mayo Clin Proc. 2005;80:74. 